\title{
ASIAKASLÄHTÖISYYS TAVOITTEENA TYÖLLISTYMISTÄ EDISTÄVÄSSÄ MONIALAISESSA YHTEISPALVELUSSA
}

Riitta-Liisa Kokko: VTT, yliopistotutkija, Helsingin yliopisto

riitta-liisa.kokko@belsinki.fi

Janus vol. 26 (2) 2018, 123-139

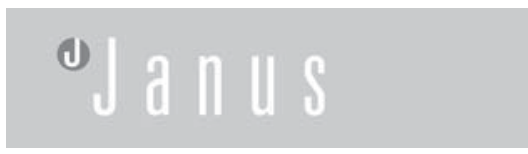

Tiivistelmä

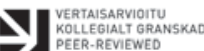

Artikkelissa tarkastellaan asiakaslähtöisyyden ilmenemistä työllistymistä edistävässä monialaisessa ja lakisääteisessä TYP-yhteispalvelussa työntekijöiden kuvaamana. TYP-palvelussa tavoitellaan henkilökohtaista, kasvokkain tapahtuvaa palvelua ja asiakaslähtöisyyttä. Millä tavoin asiakaslähtöisyys ilmenee työntekijöiden kuvauksissa TYP-palvelun asiakastyössä? Tutkimuksen aineistona ovat kuuden TYPverkoston työntekijöiden 19 teemahaastattelua. Aineiston analyysin viitekehyksenä käytettiin käsitteitä järjestys ja muutos sekä asiakkaan tilanne ja asiakkuus. Tutkimuksessa jäsentyi kolme työorientaatiota: asiakaslähtöinen, organisaatiokeskeinen ja toimenpidekeskeinen työote. Lakisääteisyys ja velvoittavuus ohjasivat palvelua organisaatio- ja toimenpidekeskeisyyteen. Asiakaslähtöisyys esiintyi asiakkaan prosessin tukemisena, organisaatiokeskeisyys palvelukokonaisuuden turvaamisena ja toimenpidekeskeisyys valintoina palvelukonseptista. TYP-palvelu tuotti yhteistyöhön järjestystä ja muutosta. Asiakaslähtöisyys toteutui suurelta osin toimenpidekeskeisen työorientaation rinnalla.

\section{JOHDANTO}

Asiakaslähtöisyys on hyvinvointipalvelujen toimintaa ohjaava periaate, joka on kirjattu erilaisiin hallinnollisiin ja toimenpideohjelmiin. Asiakaslähtöisyydellä tarkoitetaan, että palvelut organisoidaan asiakkaan tarpeista käsin. Asiakas on itse vaikuttanut palveluiden suunnitteluun ja hän tietää palvelujen kokonaisuuden ja sen, miten palveluprosessit etenevät. (Ruotsalainen 2000, 18-22.) Asiakaslähtöisyyteen kuuluu, että jokainen asiakas kohdataan omana yksilönään ja kokonaisena ihmisenä. Hänen kanssaan tehdään työtä neuvotellen ja sopimuksia tehden siten, että asiakas on aktiivisessa roolissa. "Ratkaisuja ei sanella ylhäältä eikä toimita ennalta saneltujen normien mukaan."
(Kiikkala 2000, 116) Asiakaslähtöisyys sosiaali- ja terveydenhuollon periaatteena sisältää arvoperustan ja muun muassa seuraavat arvot: ihmisarvo ja kokonaisvaltainen ihminen, kunnioitus ja aktiivisuus, itsemäärääminen ja yhdenvertaisuus, yksilöllisyys ja neuvotteleva yhteistyö, vaikuttaminen ja aitous sekä toiveikkuus ja suuntautuminen tulevaisuuteen. (emt., 116.)

Työllistymistä edistävä monialainen yhteispalvelu (TYP) vastaa pitkäaikaistyöttömien ja vaikeasti työllistyvien palvelutarpeisiin. Työttömien yhteispalvelulla tarkoitetaan vuonna 2015 voimaan tulleen lain (1369/2014) mukaan yhteistoimintamallia, jossa työ- ja elinkeinotoimisto (TE-toimisto), kunta ja Kela yhdessä arvioivat työttömien pal- 
velutarpeet, suunnittelevat työttömien työllistymisen kannalta tarkoituksenmukaiset palvelukokonaisuudet sekä vastaavat työttömien työllistymisprosessin etenemisestä ja seurannasta. TYPtoiminnan tavoite on ollut tarjota työttömille henkilökohtaista, kasvokkain tapahtuvaa palvelua (HE 183/2014; Kerminen 2015).

Eri ammattiryhmien yhteistyön tiivistäminen on nähty keskeisenä keinona pyrittäessä asiakaslähtöiseen ja kokonaisvaltaiseen työotteeseen työllistymisen tukemisessa (Arnkil ym. 2015) Sekä julkisella että yksityisellä sektorilla ollaan kiinnostuneita siitä, miten palvelu saadaan vastaamaan asiakkaiden tarpeita. Asiakaslähtöisyydestä onkin tullut palvelujen kehittämisen avainsana. Sipilän hallitusohjelmassa sosiaali- ja terveydenhuollon asiakaslähtöisyyden edistäminen on yksi hallituksen kärkihankkeista (Ratkaisujen Suomi 2015).

TYP-toiminnan taustaorganisaatiot määrittelevät lainsäädännössä, toimintaohjeissa ja asiakkuuslinjauksissa asiakaslähtöisyyden tavoitteeksi palveluissaan. Sosiaalihuoltolain tarkoitus on edistää asiakaskeskeisyyttä sekä asiakkaan oikeutta hyvään palveluun ja kohteluun sosiaalihuollossa (L 1301/2014, 1\$). Terveydenhuollossa asiakaslähtöisyyttä pidetään arvona sinänsä, mutta myös tärkeänä hoidon vaikuttavuutta ja yhdenvertaisuutta edistävänä sekä kustannuksia hillitsevänä tekijänä (Epstein ym. 2010). TE-palveluissa tavoitteena on luoda asiakaslähtöinen palvelukulttuuri ja palvelumalli sekä siirtyä viranomaiskontrollista asiakaslähtöisyyteen (Tonttila 2015). Kelassa halutaan kehittää järjestelmän asiakaslähtöisyyttä ja rakentaa asiakaslähtöistä palvelukulttuuria (As- horn ym. 2013). Edellä mainituista lähtökohdista myös henkilökohtaisen, kasvokkain tapahtuvan TYP-palvelun tavoitteena on palvelujen asiakaslähtöisyys. Tässä tutkimuksessa kysytään, millä tavoin työntekijät kuvaavat asiakaslähtöisyyttä TYP-yhteispalvelun asiakastyössä.

\section{ASIAKASLÄHTÖISYYDEN HAASTE MONIALAISESSA YHTEISTYÖSSÄ}

Asiakaslähtöisyys on käsitteenä monitulkintainen. Kuluttaja määrittyy palvelujen käyttäjäksi ja subjektiksi, asiakas puolestaan ammatillisten palvelujen vastaanottajaksi ja henkilöksi, joka tukeutuu toisiin. Asiakaslähtöisyyttä käytetään usein synonyymina asiakaskeskeisyydelle. Asiakaslähtöisyys viittaa toimintaan asiakkaan lähtökohdista hänen rinnallaan, kun taas asiakaskeskeisyys korostaa asiakasta palvelutoiminnan kohteena. (Kokko 2003, 25,27 .) Asiakkuuteen liitetään muun muassa käsitteet kuulluksi tuleminen, osallisuus, vastavuoroisuus, itsemäärääminen ja subjektina toimiminen (Laitinen 2008). Aulikki Kananoja (1997, 117) korostaa tasavertaisen yhteistyön mallia, jossa julkisorganisaatioiden palveluissa asiakas on palvelun toteuttamisen tärkeä kumppani, palveluissa korostuu vastavuoroisuus ja yhteinen vastuu. Hyvän asiakaspalvelun eräänä kriteerinä voi pitää sitä, että asiakas saa tarvitsemansa palvelut yhdessä palvelupisteessä, jossa selvitetään myös kokonaistilanne.

Asiakaslähtöisyyden kansainväliset määritelmät sosiaalitieteissä pohjautuvat asiakkaan osallistamisen, osallisuuden ja valtaistumisen käsitteisiin sekä "Advocacy and Empowerment" 
ja "Case management" -keskusteluun (Rose \& Black 1985; Davies \& Challis 1986; Freire 2005; Payne 1997; Fook 2002). Asiakaslähtöisyyden sijaan puhutaan 2000-luvulta alkaen jaetusta asiantuntijuudesta, palveluohjauksesta, dialogisuudesta ja kumppanuudesta, jotka toteutuvat asiakkaan ja työntekijän vastavuoroisessa suhteessa (esim. Parton \& O’Byrne 2000; Fook 2002; Heinonen \& Spearman 2010; Hänninen 2000). Työllisyyspalveluissa sen sijaan aktiivisen työvoima- ja sosiaalipolitiikan ja työttömien aktivoinnin toimeenpanossa korostetaan asiakkaan velvoitteita, kontrollia ja sanktioita, jolloin asiakas nähdään systeemin toimenpiteiden kohteena (Hvinden 1999; Clasen \& Clegg 2006; Arnkil ym. 2015). Asiakaslähtöisyyden sijaan käytännöt viranomaistoiminnassa ovat usein asiantuntijakeskeisiä. Tapa, jolla asiantuntijat määrittelevät asiakkaan omasta työstään käsin, edustaa asiantuntijavaltaa (Nummela 2011, 28).

Tutkimuksen kohteena olevaa monialaista TYP-yhteispalvelua on kuvattu henkilökohtaistettuna massapalveluna (personalized mass-processing), jossa tavoitellaan asiakaslähtöisyyttä. Asiakas voi myös valikoitua asiakkuuskriteerien perusteella eri sektoreiden palvelujen ulkopuolelle tai päätyä rutiinitoimenpiteiden kohteeksi. (Kokko 2003; Needham 2011; Rajavaara 2014.) Tässä tutkimuksessa jännite syntyy seuraavasta kysymyksestä: millaiselta asiakaslähtöisyys näyttää silloin, kun asiakas on lakisääteisen toiminnan osapuoli, laki velvoittaa asiakkuuteen sanktion uhalla, ja palvelu toteutetaan viranomaisten yhteistyönä organisaation rajaamasta palvelukonseptista? Asiakkaan kannalta kyse on samanaikaisesti sekä asiakkaan elämäntilanteesta, että palvelujärjestelmän asiakkuudesta, joihin molempiin etsitään TYP-palvelussa ratkaisua.

\section{TYÖLLISTYMISTÄ EDISTÄVÄN}

\section{YHTEISPALVELUN ASIAKASTYÖ}

Työllistymistä edistävälle monialaiselle TYP-yhteispalvelulle on märitelty asiakkuuskriteerit työttömyyden keston ja monialaisen palvelutarpeen perusteella. Kun työtön on saanut työmarkkinatukea vähintään 300 päivää tai on ollut yhdenjaksoisesti työttömänä vähintään 6 kuukautta (alle 25-vuotiaat) tai 12 kuukautta (25 vuotta täyttäneet), TE-toimisto, kunta ja Kela arvioivat monialaisen yhteispalvelun tarpeen. Monialainen yhteispalvelu alkaa intensiivisellä, enintään kolmen kuukauden kartoitusjaksolla, jonka aikana työttömän palvelutarve arvioidaan monialaisesti ja hänen kanssaan laaditaan monialainen työllistymissuunnitelma. Suunnitelmassa sovitaan työttömän palvelutarpeen edellyttämistä työvoima-, sosiaali-, terveys- ja kuntoutuspalveluista. Tavoitteena on tukea asiakkaan sijoittumista avoimille työmarkkinoille. (HE 183/2014 vp.)

TYP-toiminta perustuu kuntien, TEtoimistojen ja Kelan yhteistyösopimukseen, lähtien näiden eri tahojen omista toimivaltuuksista. Työttömälle monialainen yhteispalvelu tarjoaa tukea työllistymiseen sekä viranomaistoimien yhteensovittamista. Työtön on velvollinen osallistumaan monialaisen työllistymissuunnitelman laatimiseen ja tarkistamiseen, toteuttamaan hänen kanssaan laadittua suunnitelmaa sekä hakeutumaan ja osallistumaan suunnitelmassa sovittuihin palveluihin. Työtön 
on myös velvollinen suunnitelmassa sovitussa määräajassa ja sovitulla tavalla ilmoittamaan suunnitelman laatimiseen osallistuneille viranomaisille, miten hän on toteuttanut suunnitelmaa. Velvollisuuksien laiminlyönti vaikuttaa hänen oikeuteensa saada työttömyysetuutta tai toimeentulotukea. Työ- ja elinkeinotoimisto ja kunta ovat velvollisia selvittämään työttömälle kuuluvat velvollisuudet. (L1369/2014, 5\$.)

TYP-yhteispalvelussa käydään TEtoimiston, sosiaali- ja terveystoimen ja Kelan työntekijöiden yhteisïa sekä työntekijöiden ja asiakkaiden välisïä neuvotteluja. Anselm Straussin (1978) mukaan neuvotteluissa rakennetaan kommunikaation kautta yhteistyötä ja ihmisten välisiä verkostoja, jotka yhdessä muodostavat sosiaalisia järjestyksiä. Strauss kutsuu tätä käsitteellä neuvoteltu järjestys, jossa tavoitteena on saada aikaan järjestystä ja muutosta neuvoteltavaan asiaan. Neuvottelu, asioista sopiminen ja yhteisten päätösten tekeminen voi olla tiedostettua ja tavoitteellista tai se voi toteutua jokapäiväisenä arkirutiineihin liittyvänä toimintana. Neuvotellun järjestyksen tavoitteena on luoda yhteisymmärrystä toimijoiden välille ja rakentaa eri organisaatioissa vallitsevista työkulttuureista, toimintaperiaatteista ja tavoitteista yhdistelmä, jonka varassa yhteistyö voi jatkua ja tavoitteet saavutetaan. (Strauss 1978, 5-7, 157.)

TYP-verkostoa voi kuvata institutionaalisena toimintana, jossa lainsäädäntö ja organisaatioiden omat tavoitteet määrittävät yhteistyötä, viranomaiset toimivat omien taustaorganisaatioidensa edustajina, toiminta noudattaa vakiintuneita käytäntöjä ja asiantuntijat käsittelevät asiakkaan elämäntilannetta osana palvelujärjestelmän asiakkuutta (Strauss 1978, 5-7). Monialaisessa yhteispalvelussa asiakkaan palvelukokonaisuus, viranomaisten yhteistyö ja työllistymiseen tähtäävät toimet ovat neuvottelua vaativia tilanteita, joissa tavoitteena on tuoda järjestystä ja muutosta asiakkuuden ja asiakkaan tilanteisiin.

\section{TUtKIMUSTEHTÄVÄ, AINEISTO} JA ANALYYSIN TOTEUTUS

Tutkimus on Kelan rahoittama ja kuuluu Helsingin yliopiston ja Terveyden ja hyvinvoinnin laitoksen vuosina 20162018 toteuttamaan "Työllistymistä edistävä monialainen yhteispalvelu paikallisena hallintana" -tutkimuskokonaisuuteen. Tämän artikkelin tarkoitus on selvittää, millä tavoin asiakaslähtöisyys ilmenee monialaisessa TYP-yhteispalvelussa työntekijöiden kuvaamana.

Tutkimusaineistona ovat Uudenmaan kuuden TYP-verkoston 19 työntekijän teemahaastattelut vuosina 2016-2017. Litteroitua haastatteluaineistoa muodostui 176 sivua. Haastateltavat toimivat Kelan työkykyneuvojina, TE-toimistojen asiantuntijoina sekä kuntien sosiaali- ja terveystoimen työntekijöinä ja he työskentelevät asiakastyössä monialaisessa TYP-verkostossa osa- tai kokoaikaisesti. Haastateltujen erilaisia ammattinimikkeitä ovat muun muassa sosiaalityöntekijä, sosiaaliohjaaja, terveydenhoitaja, sairaanhoitaja, työkykyneuvoja, uraohjaaja, psykologi ja asiantuntija.

Strukturoidut teemahaastattelut on toteutettu puhelinhaastatteluina, litteroitu ja analysoitu temaattisen sisällönana- 
lyysin avulla. Haastateltavilta kysyttiin useista teemoista ja yhtenä kysymyksenä oli: "mitä asiakaslähtöisyys tarkoittaa työssäsi?" Tutkimus on tapaustutkimus, jossa paikallista työllisyyden hallintaa tarkastellaan omassa toimintaympäristössään Uudenmaan alueella. Tapaustutkimuksen avulla pystytään vastaamaan etenkin miten ja miksi -kysymyksiin. (Yin 2014.)

Laadullisen tutkimuksen tavoitteena on tehdä ilmiö ymmärrettäväksi ja selittää se paikallisesti (Alasuutari 1999, 237). Tutkimuksen viitekehys muodostuu käsitteistä ja niiden välisistä merkityssuhteista. Ensimmäiseksi tutkimus on toteutettu yhdistämällä aineistolähtöinen ja teoriaohjaava sisällönanalyysi. Analyysiyksiköt on valittu aineistosta ja samalla aikaisempi tieto ohjaa ja auttaa analyysia. (Tuomi \& Sarajärvi 2013, 96-97.) Neuvotellun järjestyksen lähtökohdista TYP-palvelua on jäsennetty järjestyksen ja muutoksen (Strauss 1978) sekä asiakastyötä asiakkaan tilanteen ja palvelujärjestelmän asiakkuuden (Kokko 2003) käsitteitä apuna käyttäen. Analyysirungon sisälle muodostui erilaisia asiakaslähtöisen työskentelyn teemoja ja sisältöjä.

Toiseksi analyysi toi esiin, että haastateltavat kuvasivat asiakaslähtöisyyttä TYP-toimintaa ohjaavana lähtökohtana ja perusarvona, kuten "täällä toimitaan asiakaslähtöisesti". Tämän lisäksi he asiakaslähtöisyyttä kuvatessaan käyttivät sekä organisaation näkökulmaa että toimenpiteiden käsitteitä. Asiakaslähtöisyyden yhteydessä puhuttiin organisaation ja toimenpiteiden lähtökohdista. Alasuutarin $(1999,225)$ mukaan aina, kun tutkija löytää aineistosta vihjeen jonkinlaisen normin olemassaolosta, hän on törmännyt ristiriitaan. Tämä havainto ohjasi analyysin toista vaihetta, jossa analyysikehikkoon muodostettiin kolme ulottuvuutta: asiakaslähtöisyys, organisaatiokeskeisyys ja toimenpidekeskeisyys. Näitä ulottuvuuksia kutsutaan tutkimuksessa kolmeksi työorientaatioksi. Analyysikehikko sisältää siten neljä tasoa, jotka ovat asiakkaan tilanne, asiakkuus, järjestys ja muutos sekä kolme ulottuvuutta, jotka ovat asiakaslähtöinen, organisaatiokeskeinen ja toimenpidekeskeinen työorientaatio. Analyysin tulokset on kiteytetty tuloslukujen yhteenvedossa, kuviossa 1.

Seuraavaksi tarkastellaan analyysin tuloksia työntekijöiden kuvauksista TYP-yhteispalvelun asiakastyössä. Aineistositaatit ovat haastattelujen suoria lainauksia, joista on poistettu ainoastaan täytesanoja. Lauseita on yhdistetty merkityskokonaisuutta muuttamatta kolmella pisteellä (...). Haastateltavien taustaorganisaatioita ei ole mainittu ja haastateltavat on nimetty lyhentein (H1, H2).

\section{AsIAKASLÄHTÖISYYS TYÖORIENTAATIONA}

Asiakkaalle lähetettävä kutsu TYP-palveluun on lähtökohtaisesti lainsäädäntöön perustuva viranomaistoimenpide, jonka perusteella toimintaa ei voi pitää asiakaslähtöisenä. Asiakas ei voi saapua palveluun oma-aloitteisesti, vaan viranomaiset kutsuvat hänet tapaamiseen. Yhteispalvelua on voinut edeltää useita vuosia kestänyt asiakkuus työttömänä työnhakijana.Yleensä asiakkaat valitaan asiakasrekisterien perusteella, kutsu on velvoittava ja sen noudattamatta jättäminen voi johtaa karenssiin määräajaksi. 
"Semmonen info kaikesta sille asiakkaalle. Se on pitkä, kahden tunnin mittainen. Eli silloin mä näytän kaikki ohjelmat, mistä häntä kirjataan ja vielä käydään läpi se TYP ja käydään läpi tällainen laaja-alainen palvelutarpeen arviointi. Sitten otetaan vielä suostumus yhteistyöhön ja käydään läpi kaikki yhteistyökumppanit ketä voi olla... Mä nään sen asiakaslähtöisyyden sillein, että mä kovasti painotan tässä asiakkaalle, yhdessäkin painotetaan, että asiakas itse suostuu, haluaako hän olla tässä TYPtoiminnassa ja asiakkuudessa ja sitten mahdollisuuksista. Ja sitten asiakkaan ääni kuuluu siinä.” (H8)

Haastateltavat kertoivat, että asiakkuuden alussa työttömältä pyydetään kirjallinen suostumus yhteistyöhön. Yhteispalvelussa asiakastiedot, asiakkaan tilannekuvaus, palvelutarpeen arviointi, työllistymissuunnitelma ja muut olennaiset tiedot kirjattiin TYPPI-tietojärjestelmään. Allekirjoituksellaan asiakas sitoutui yhteistyöhön, joka sisälsi asiakaskirjaukset ja viranomaisten tietojenvaihdon. Edellä mainitut toimenpiteet ovat TYP-asiakkuuden ehtoja, joista asiakas ei voi kieltäytyä tai neuvotella. Työntekijä kuvasi toimintaa asiakaslähtöisenä ja painotti alkutapaamisessa asiakkaan äänen kuulumista, mutta käytännössä kuuleminen oli näennäistä, koska asiakkaalla ei ole mahdollisuutta vaikuttaa suostumuksen sisältöön tai yhteistyön luonteeseen.

Asiakkaan elämäntilanne on asiakaslähtöisen yhteistyön lähtökohta. Asiakas katsoo viranomaisten palveluja omasta elämäntilanteestaan ja palvelutarpeistaan käsin. TYP-työskentelyyn kuuluu asiakkaan elämäntilanteen selvittäminen, palvelutarvekartoitus ja monialaisen työllistymissuunnitelman laatiminen yhdessä asiakkaan kanssa. Kokonaistilanteen selvittäminen sisälsi sosiaalisen ja terveydellisen tilanteen, työhistorian ja ammatillisten valmiuksien sekä taloudellisen tilanteen ja tulevaisuuden tavoitteiden tarkastelun. Laajan alkukartoituksen voi katsoa palvelleen työntekijöiden työtä enemmän kuin asiakasta. TE-toimiston ja kunnan työntekijät toimivat yleensä työparina ja pyysivät tarvittaessa kuntoutuskysymyksissä mukaan Kelan asiantuntijan. Työllistymissuunnitelmassa sovittiin palvelutarpeen mukaisista työvoima-, sosiaali-, terveys- ja kuntoutuspalveluista ja niiden toteutumisen seurannasta. Pitkäaikaistyöttömillä on usein vuosien aikana kasaantuneita palvelutarpeita, he tarvitsevat aikaa asioiden selvittelyyn ja ymmärtävää tukea, etenkin jos "elämäntilanne on kauheen riekalainen tai alkaa paljastua mielenterveysongelmia.” (H14)

"Mun mielestä mä voin toimii tosi paljon asiakaslähtöisesti, että se on mun työn suuri etu ... me ollaan usein sen asiakkaan tilanteen ymmärtäjiä, myös siinä heidän TYP-asiakkuudenkin kannalta. Että heillä on, voi olla siinä jotain ongelmia. Ylipäänsä se luottamuksellinen keskustelu, mihin yritetään päästä asiakkaan kanssa. ... että pyrkimys ois oikeesti ymmärtää asiakasta." (H18)

Asiakaslähtöistä työotetta kuvattiin vastavuoroisena ja ymmärtävänä kohtaamisena ja luottamuksellisena keskusteluna. Työntekijä toi oman asiantuntemuksensa asiakkaan käyttöön, selvitti kokonaistilannetta ja vei asioita eteenpäin palvelujärjestelmässä. Sosiaalipalveluissa viranomaiset nähdään usein asiantuntevina tietäjinä ja asiakaslähtöisinä ymmärtäjinä (Jokinen 1995, 145). TE-palveluissa asiakaslähtöisyyt- 
tä toteutetaan keskeisesti palveluohjauksena (Arnkil ym. 2015, 68-72), ja Kelassa tehtävä asiakaspalvelutyö on pääasiassa asiakaspalvelijoiden neuvontatyötä (Heinonen 2009, 35-36). Asiakkaan kohtaamisessa luottamus, aito kuunteleminen ja kuuleminen ovat tärkeimpiä toimintaperiaatteita (Sipilä 2011, 103). Luottamuksen ilmapiiri vahvistaa asiakkaan uskoa itseensä ja palvelujärjestelmän kykyyn auttaa häntä selviytymään vaikeasta tilanteesta. (Kokko 2003, 146.)

Asiakaslähtöisyys toteutui myös siten, että keskustellen löydettiin asiakkaan motivaatio, jolloin voitiin tukea hänen tavoitteitaan ja osallisuuttaan. Motivaatio ja asiakkaan omat tavoitteet olivat myös tavoitteellisen muutostyön lähtökohta. Ne löydettiin keskittymällä henkilön vahvuuksiin sekä asioihin, joihin oli mahdollista vaikuttaa muutoksen aikaansaamiseksi.

"Ja sitten ehkä keskittymällä asiakkaan vahvuuksiin ja miettimällä, et mikä se asiakkaan tavoite on ja mikä on tavallaan se pieni juttu, mistä vois lähtee liikkeelle, mikä vois toimia. Ja jotenkin et kokis, et joku asia voi muuttuu. Mä aina sanon, että mikään ei muutu, jos mikään ei muиtu. Ja toisaalta puhun myös asiakkaan unelmista, että onks nyt joku semmoinen juttu, että mitä haluais tavoitella.” (H14)

"Koen, että pystyy hyvinkin toimimaan asiakaslähtöisesti. Ja se on tietenkin meidän toiminta tai mun mielestä se ohjaava asia. Täällä toimitaan asiakaslähtöisesti. ... Lähdetään asiakkaan suunnitelmaa siinä toteuttamaan. Tietenkin annetaan työkaluja siihen asiakkaalle. Tietenkin näin, että kaikin tavoin tuetaan sitä asiakasta, että hän ei tee meijän virkailijoiden suunnitelmaa, vaan hän toteuttaa sitä omaa suunnitelmaa.” (H13)

TYP-palvelussa asiakkaan elämäntilannetta tuettiin muun muassa muutostyössä, motivoimalla ja tukemalla elämänhallintaa, joita kuvattiin asiakastyön työotteina. Motivoiva haastattelu, intensiivinen ja räätälöity tuki sekä joskus jalkautuminen asiakkaiden arkeen tulivat työkäytäntöinä esiin. Haastateltavat kertoivat, että he lähtevät toteuttamaan asiakkaan suunnitelmaa. Kuvauksissa välittyi pyrkimys kuulla aidosti asiakasta ja hänen tarpeitaan, mitä hän haluaa, mistä on kiinnostunut ja mihin suuntaan hän haluaa elämässään edetä.

Asiakkuus TYP-toiminnassa merkitsee pirstaleisen palvelujärjestelmän kokoamista, jotta työtön saa nopeammin ja tarkoituksenmukaisempana kokonaisuutena ne eri viranomaisten palvelut, joita hän tarvitsee työllistyäkseen (Kerminen 2015). Kukin viranomainen toteutti oman taustaorganisaation palveluja, ja yhteistyössä sovittiin, kuka toimii asiakkaan vastuutyöntekijänä. Sosiaaliset ongelmat olivat usein kasautuneita ja vaativat pitkäjänteistä ja suunnitelmallista työotetta. Tällaisten ongelmien kanssa työskentelyyn tarvitaan verkostossa toivoa ylläpitävää työotetta ja pienten edistysaskelten kunnioittamista (Kokko \& Veistilä 2016, 229).

\footnotetext{
”... mun mielestä [on] tarkoituksenmukaista, kun se menee vaikka pienin askelin eteenpäin. Et siellä on jotakin muutosta. Et jollakin tavalla pystytään poistamaan niitä työllistymisen esteitä. Tai saattamaan se asiakas oikeisiin palveluihin." (H8)
}

TYP-palvelun asiakkuudessa oli olennaista, että työtön sai henkilökohtaista 
palvelua ja ammattilaisten tukea oman polun rakentamiseen ja työllistymiseen yhdestä palvelupisteestä. Työllistymissuunnitelmaan kirjattiin mahdollisimman realistinen työelämä-, koulutus- tai kuntoutustavoite ja tarvittavat toimet näiden tavoitteiden saavuttamiseksi.Yksilökohtaisissa, suorissa asiakaskontakteissa työntekijä voi ja hänen kuuluu tuoda asiakkaalle esiin erilaisia vaihtoehtoisia toimintamalleja, mutta hän ei voi päättää asiakkaan puolesta, mitä tämän täytyy tehdä (Kilpeläinen 2009, 76).

”Että lähdetään työkokeiluista - mikä on ihan työtä - tietenkin se tavoite on aina se työllistyminen, mutta tavallaan se reitti mitä kohti sitä työtä lähdetään, niin valitaan siinä pikkuhiljaa. Että ei siinäkään tarvii heti tietenkään asiakkaalla olla selkeänä sen ensimmäisen käynnin jälkeen, että miten lähdetään etenemään. Kyllä ne aika pitkii prosesseja tosissaan on.” (H13)

"Tää on nimenomaan tavoitteellista, pitkäkestoista muutostyötä ja muutos ei tapahdu kovin helposti, silloin kun siellä on niitä ongelmia. Mä nään tään äärimmäisen tärkeänä palveluna.” (H10)

Neuvotellun järjestyksen näkökulmasta TYP-palvelua voi kuvata toimintana, jossa tavoitellaan järjestystä ja muutosta asiakkaan arkeen ja asiakkuuteen. Asiakaslähtöisessä toiminnassa toteutuivat nämä molemmat tasot. Osa asiakkaista tarvitsi tukea arkielämän hallintaan, jolloin työntekijät auttoivat asiakasta muutostyössä ja lukkiutuneessa tilanteessa löydettiin yhtäältä tarvittavat palvelut ja asiakkaan omat vahvuudet, osaaminen ja tavoitteet. Myönteiset muutokset lisäsivät asiakkaiden elämänhallintaa, poistivat työllistymisen esteitä ja lisäsivät omatoimisuutta. Asiakasprosessia kuvattiin tavoitteellisena muutostyönä, joka oli motivoivaa, kannustavaa, intensiivistä tai ylläpitävää yhteistyötä asiakkaan kanssa.

Työntekijöillä oli vastuu asiakkuusprosessin seurannasta. Varsinkin nuoret tarvitsivat paljon apua konkreettisissa asioissa. Työntekijä totesi tehneensä toisinaan liikaa asiakkaan puolesta, mikä ei tukenut omatoimisuutta ja joskus hän oli olettanut asioiden tulevan hoidetuiksi, eikä nähnyt esteenä olevia haasteita ja pulmia, jolloin hän tuki asiakasta liian vähän. Työntekijä kuvasi tilannetta jatkuvaksi tasapainoiluksi. Asiakaslähtöisessä yhteistyössä pyrittiin katsomaan asiakkaan etua ja toimimaan siten, että asiakas ei ole toimenpiteiden kohde, vaan aktiivinen ja toimiva subjekti sekä tasavertainen yhteistyökumppani.

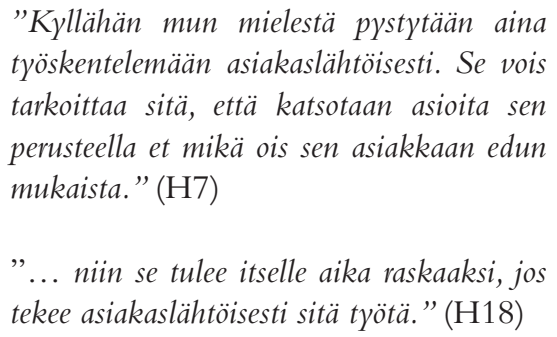
työskentelemään asiakaslähtöisesti. Se vois tarkoittaa sitä, että katsotaan asioita sen perusteella et mikä ois sen asiakkaan edun mukaista." (H7)

"... niin se tulee itselle aika raskaaksi, jos tekee asiakaslähtöisesti sitä työtä.” (H18)

Eräs työntekijä totesi, että asiakaslähtöinen toiminta ja asiakkaan pitäminen mukana omassa työskentelyssä tekee työn raskaaksi. Joidenkin haastateltujen mukaan asiakaslähtöisyys oli myös työntekijöiden yhteistyötä hiertävä asia ja kipuilun aihe. Periaatteet asiakkaan aktiivisuudesta, osallistumisesta, subjektiudesta ja asiantuntijuudesta voivat olla ristiriidassa todellisten työkäytäntöjen kanssa (esim. Rissanen 2015). 


\section{ORgANISAATIOKESKEINEN TYÖORIENTAATIO}

Toisenlaista työorientaatiota haastateltavat kuvasivat TYP-palvelun organisaatiokeskeisenä palvelutoimintana. Lakisääteisen toiminnan tavoitteisiin, kuten toimijoiden työnjaon selkeyttämiseen, työttömän työllistymisen edistämiseen ja palvelujen yhteensovittamiseen (Kerminen 2015), vastattiin organisaatiokeskeisellä toiminnalla. Yhtäältä viranomaisten toimintaa ohjaavat yhteispalvelun taustaorganisaatiot, niiden lainsäädännölliset tehtävät, ammatilliset ohjeet ja arjen käytännöt, joita yhteensovitetaan TYP-palvelun monialaisessa yhteistyössä.

TYP-palvelun organisaatiokeskeisyyttä kuvasi käytäntö, jossa asiakkaita tavattiin ja elämäntilanteita selvitettiin avokonttorissa. Luottamuksen syntymistä esti asiakkaiden henkilökohtaisten asioiden, myös sairauksien ja lääkitysten, käsittely avokonttorissa ulkopuolisten kuullen. Elämäntilanteiden taustalla voi olla rankkoja kokemuksia, pettymyksiä tai pelkoa sanktioista ja tällöin asiakkaan oikeus yksityisyyteen, tietosuojaan ja luottamukselliseen keskusteluun ei toteutunut. Organisaation ehdoilla toimittaessa asiakkaan asema ja arvostus yhteistyön osapuolena jäi alisteiseksi. Viranomaispalveluissa asiantuntijan toimintaan liitettiin samanaikaisesti tuen, kontrollin ja sanktioiden mahdollisuus.

"Eiväthän he - asiakkaat - kerro kaikkee aina ensimmäisellä tapaamisella, kenet he tapaa. Sit on sitä, että yhdelle puhutaan yhtä ja toiselle toista. Niin, silleen se on ehkä ihan hyvä, että kartoitetaan [yhteispalaverissa]se tilanne, mikä sit on.” (H1)
Haastateltavat toivat esiin ammatillisen epäilyn, jonka mukaan he eivät aina luota asiakkaisiin ja heidän kertomaansa. He totesivat, että asiakkaiden kertomukset eri työntekijöille saattoivat vaihdella tilanteen mukaan. Ammatillinen harkintavalta perustuu luottamukseen (Freidson 2001, 23-26) ja työntekijöiden tehtävänä voi olla esimerkiksi etuuskysymyksissä tarkistaa asiakkaiden antaman tiedon paikkansa pitävyys. Myös asiakkaat avautuivat asioistaan vasta vähitellen, jolloin luottamuksellisen yhteistyön rakentaminen vei aikaa.

Organisaatiokeskeisyys ilmeni myös asiakkuuden hallinnointia koskevassa puheessa ja TYP-toiminnan tuloksellisuuteen kohdistuvissa odotuksissa. Työntekijät kuvasivat ristiriitaa työn laadullisten ja määrällisten tavoitteiden kesken, jolloin vastakkain asettuivat asiakastyö ja tilastolliset tavoitteet. Haastateltavat painottivat asiakkaan kohtaamista, aikaa ohjaukseen ja tavoitteelliseen muutostyöhön. Hallinto ja johto sitä vastoin mittasivat työn tuloksellisuutta asiakasmäärien $\mathrm{mu}-$ kaan, odottivat nopeaa asiakasvirtaa ja asiakkaiden ohjaamista eteenpäin palveluihin. Haastateltavien mukaan yksilöllinen asiakastyö tuotti hyviä tuloksia, mutta merkitsi samalla tarvetta rajata asiakasmääriä, niin että työntekijällä oli aikaa tavata asiakasta.

\footnotetext{
"Sanotaan näin, että laatuun pitäis kiinnittää huomiota. Laadulliset muuttujat, että jos noihin määrälisiin muuttujiin mennään, niin sit se on just tätä, et jaha et nyt on näin ja näin paljon asiakkaita kuntouttavassa työtoiminnassa. Nyt on näin ja näin paljon työkokeilussa asiakkaita. Ja se ei kerro mistään mitään, mitään näitten henkilöitten. Se voi olla, että me pilataan koko henkilön tu-
} 
levaisuus sillä, kun hän hautautuu jonnekin kuntouttavaan puoleks vuodeksi - vuodeksi." (H7)

Asiakkuuden hallinnoinnissa viranomaiset neuvottelivat yhteispalavereissa, tapasivat asiakkaita työparina, yksin tai tiimissä sekä konsultoivat toisiaan tietojärjestelmien kautta. Osa haastateltavista korosti, että asiakas on mukana kaikissa vaiheissa, hänelle annetaan tietoa kaikesta toiminnasta eikä toimita selän takana. Jotkut puolestaan toivat esiin, että asiakkuutta siirretään eteenpäin ja asiakkaita ohjataan palvelusta toiseen, ilman että asiakkaille itselleen muistetaan tästä kertoa.

"On mun mielestä se ongelma, että ne ei tiedä, niille ei oo kerrottu edes että ne on siirretty meille. ... Että nyt teidät on siirretty tänne ja tänne.” (H12)

”... mikä olis aina se paras taho ottamaan sen asiakkaan tilanteen haltuun. ... Mun mielestä on liikaa sellaista, että asiakas aina ohjataan johonkin toiseen paikkaan ja mä väitän että se, että asiakas moneen kertaan elämänsä aikana jonkun työttömyysjakson aikana ohjataan aina johonkin seuraavaan paikkaan, kun tää ei oo ehkä ihan se oikea paikka sulle tässä kohtaa, niin se voi olla just sellainen syrjäytymistä edistävä tekijä. Ja semmoisesta meidän pitäisi päästä pois." (H19)

Monialaisessa yhteistyössä voi olla epäselvää, kuka kantaa ensisijaisen vastuun asiakkuudesta. Straussin (1978, 5-7) mukaan yhdessä toimiminen edellyttää neuvottelua, vuorovaikutusta ja keskinäisiä sopimuksia yksityisten ja julkisten tavoitteiden saavuttamiseksi. TYP-palvelussa koordinoitiin sektoroituneen palvelujärjestelmän pirstaleisuus ja sovittiin asiakkaan vastuutyöntekijästä. Palvelutarvearviossa vastuun otti sosiaalityöntekijä tai -ohjaaja, työllistymissuunnitelman ja työllisyyspalvelujen osalta TE-toimiston asiantuntija ja kuntoutuspalveluissa Kelan työkykyneuvoja.

"Meidän pitäis kaikkien ymmärtää, mitä meillä kaikilla on tarjottavana.... Tässä on se haaste kun tässä ei voi vaan ottaa sitä omaa näkökulmaansa huomioon, vaan nimenomaan pyrkiä tajuamaan se koko kokonaisuus ja kaikkien näkökulmat ja kaikkien mahdollisuudet. Ja sitten niistä pystyä neuvottelemaan ja mikä tärkeintä, pystyä asiakkaalle ymmärrettävästi selittämään sitä kokonaisuutta tai tarjota oikeanlaisia juttuja oikeassa kohdassa. Onhan niin, että on ihan hirveästi kaikenlaisia palveluita." (H19)

Yhteispalvelussa asiakas ohjattiin tarvittaviin sosiaali- ja terveyspalveluihin, kuntoutus- ja työllisyyspalveluihin. Valintojensa perusteeksi asiakas tarvitsi työntekijöiltä tietoa palveluista ja niihin hakeutumisesta. Asiakkaan omatoimisuutta ja itsemääräämistä ei tukenut, jos työntekijät tekivät päätöksiä asiakkaan puolesta.Tällöin syntyi kuva, että työntekijät tietävät asiakasta paremmin, mitä tämä tarvitsee. Toiminta näytti organisaatiokeskeiseltä, vaikka perusteluina saatettiin käyttää asiakkaan etua.

"Mehän tehdään aina suunnitelmat ... vii-
me kädessä asiakas sitten hyväksyy sen tai
ei. Jos se kieltäytyy meidän palveluista tai
ei halua niihin, nii me ei niitä tyrkytetä." (H10)

Tuen ja kontrollin raja voi olla hyvin häilyvä ja asiakkaan osaksi jäi joko hyväksyä tai hylätä hänelle tehty suunni- 
telma. Useat työntekijät kuitenkin korostivat, että he lähtevät toteuttamaan asiakkaan tavoitteita ja suunnitelmia. Suunnitelma oli kuitenkin viranomaisten laatima ja asiakkaan tehtävänä oli toteuttaa suunnitelma sekä raportoida siitä viranomaisille.

\section{TOIMENPIDEKESKEINEN TYÖORIENTAATIO}

Kolmantena työorientaationa asiakaslähtöisyyden ja organisaatiokeskeisyyden rinnalla aineistossa esiintyi toimenpidekeskeisyys. Palvelukokonaisuutta kuvattiin usein yksilöityinä toimenpiteinä, jolloin asiakkaan palveluprosessi pilkottiin pienempiin toimenpiteisiin. Toimenpiteitä voitiin hallinnoida ja laskea suoritteina, jolloin muodostui kuva toiminnan tehokkuudesta ja tuloksellisuudesta. Työllisyyspalveluissa parantavia toimenpiteitä kuvataan palvelujen tehostamisena ja aktiivisen työvoimapolitiikan toimenpiteillä ihminen integroidaan normaaliin työelämään. (Arnkil ym. 2015; Tonttila 2015.)

Haastateltavat rinnastivat asiakaslähtöisen ja toimenpidekeskeisen työotteen ja kuvasivat asiakaslähtöistä työskentelyä palveluvalikoiman toimenpiteillä, joissa asiakas päättää, kenen toimenpiteisiin lähtee. Työntekijöiden kuvauksissa toimenpidekeskeisyys asettui lähemmäs organisaatiokeskeistä kuin asiakaslähtöistä toimintaa. Työelämään motivointi ja kannustus on usein toimenpiteisiin keskittyvä työote ja keino saada asiakas liikkeelle, usein myös rajoja asettamalla.

"Siinä se asiakaslähtöisyys tavallaan myös on, että hän ite on mukana siinä. Sehän se on joka kuitenkin päättää mihin, mitä pal- veluita lähetään, mihin suuntaan lähetään, kenen toimenpiteisiin.” (H5)

"Joillekin toimii paremmin se, että asetetaan ne tosi tiukat rajat, että nyt tähän mennessä hoidat tämän jutun ja tää on saatava, että muuten toi asia ei lähde menemään eteenpäin. Et se toimii toisilla, mutta sitten toisilla toimii sit taas se hirveen hyvin, että niitä kannustaa ja motivoi, ja ne innostuu itekki, että vitsi, et tää on tosi hyvä juttu. Ja että kyllä siinä joutuu vähän erilaisia tekniikoita käyttään ja miettiin.” (H14)

Asiakkuutta ratkaistiin ohjaamalla asiakas tarpeenmukaisiin toimenpiteisiin. Asiakaslähtöisyys ja toimenpidekeskeisyys kohtasivat TYP-toiminnassa siten, että asiakkaalle esiteltiin palvelutarjotinta ja hän sai valita palvelukonseptista itselleen sopivan palvelun. Hänelle annettiin miettimisaikaa ja vaihtoehtoja käytiin yhdessä läpi. Työntekijät korostivat asiakkaan ohjausta ja valinnanvapautta toimenpiteissä etenemiseen. Toiminta muistuttaa palveluohjauskäytäntöä, vaikka sitä ei tällä käsitteellä mainittu.

"Ja ihmiset tarvii henkilökohtaista ohjausta.... Nää ihmiset tarttee ohjauksellista otetta, perehtymistä. Niin silloin ei voi yhdellä ihmisellä hirveesti niitä ohjattavia olla." (H18)

Myös järjestystä palveluihin pyrittiin saamaan aikaan esittelemällä asiakkaalle palvelukonseptin mukaista palvelutarjotinta. Ideana oli, että asiakas siirtyi itseohjautuvasti tarjottimesta ja palvelusta toiseen, hänet saatiin nopeasti toimenpiteisiin ja tilaa uusille asiakkaille. Työntekijät totesivat, että laaja palvelutarjonta näyttäytyy asiakkaille pirstaleisena, jolloin he tarvitsevat tietoa 
valintojen pohjaksi.Vaikeassa elämäntilanteessa valinnat voivat kuitenkin olla näennäisiä tai ne tehdään viranomaisten ehdotusten perusteella.

Toimenpiteisiin keskittymisen voi katsoa merkitsevän asiakkaalle valinnanvapautta, jossa hän voi valita toimenpiteen, johon osallistuu. Toimenpiteisiin keskittyminen toi jännitteen asiakastyöhön. Osa työntekijöistä kuvasi asiakkaan kanssa tehtävää yksilötyötä laadullisena työotteena, osa puolestaan kertoi tavoitteesta ohjata asiakas tehokkaasti sopiviin työllistymisen tukitoimiin. Palvelupolku ja -prosessi saattoi jäädä sirpaleiseksi ja sattumanvaraiseksi, jolloin asiakas tarvitsi palvelukokonaisuuden jäsentämiseen työntekijän tukea.

"Että siinä on joku ottanut vastuun siitä asiakkaasta. Ja sit pyritään, pystytään takaamaan, että asiakkaan työntekijät ei jatkuvasti vaihdu, eikä sitä henkilön, asiakkaan asioita [hoideta]sillä tavoin että hänet vaan laitetaan jonnekin toimenpiteeseen. Ja sitten jos systeemi ikään kuin palkitsee siitä, että hän on toimenpiteessä, niin joo hyvä. Vaan se, että se on tän asiakkaan edun mukaista ja rakennetaan se palvelu sitä kautta." (H7)

"Ollaan ehkä enemmän menty siihen, että asiakas otetaan sisälle ja mahdollisimman nopeesti yritetään päästä siitä poies, saada jonnekin toimenpiteeseen.” (H1)

TYP-palvelussa haettiin järjestystä ja muutosta myös ammattilaisten keskinäiseen yhteistyöhön, työn- ja vastuunjakoon. Erilaiset työorientaatiot pohjautuivat pitkälti yhteistyöorganisaatioiden ja ammattilaisten työn tekemisen tapoihin, joita pyrittiin yhteensovittamaan. Toimivien käytäntöjen rinnalla myös ilmeni, että TYP-palvelussa eri organisaatioiden ja ammattilaisten tehtävät olivat toisaalta eriytyneet, toisaalta sekoittuneet keskenään ja tästä oli aiheutunut yhteistyöhön hämmennystä ja jännitteitä. Työtehtävissä tarvittiin toistuvaa rajankäyntiä siitä, kenen tehtävistä milloinkin on kysymys, kuinka toimenpiteet yhteensovitetaan ja kenellä on vastuu asiakkuudesta.

"Sit tulee tavallaan sitä keskustelua, että noh - nyt te tulette tähän meidän tontille työskentelemään. Ja se on semmoista rajankäyntiä.... Ja se erilainen koulutuspohja ja se ajatusmaailma, niin kyllä haittaa aika usein työskentelyä....Että keskustelua ja asioiden määrittelyä tarvitaan jatkuvasti... Sit just kokouksessa käydään läpi sitä, että mitä kunkin ammattiryhmän pitää tai voi tehdä ja sit tarvitaan erilaisii ohjeita siitä että miten sitten tässä yhteisesti toimitaan.” (H11)

Haastatteluissa ei tullut juuri lainkaan esiin, miten suunnitelmat laitetaan käytäntöön asiakkaiden arjessa.TYP-palvelussa tämän vaiheen jääminen taustalle voi johtua siitä, että TYP-lain mukaan työtön on velvollinen suunnitelmassa sovitussa määräajassa ja sovitulla tavalla ilmoittamaan suunnitelman laatimiseen osallistuneille viranomaisille, miten hän on toteuttanut suunnitelmaa (L 1369/14). Asiakkaan tehtävänä oli olla aktiivinen, toimia yhteisesti valituissa toimenpiteissä ja raportoida työntekijöille toiminnastaan ja tilanteessa tapahtuneista muutoksista. Työttömien palvelu voidaan siten nähdä ennen kaikkea keinona kohti työllistymistä, jolloin työttömän aktiivisuus kohdistuu avoimille työmarkkinoille ja palvelun kautta parannetaan henkilön työmarkkinaresursseja (Elonen ym. 2017, 289). 


\begin{tabular}{|c|c|c|c|}
\hline & $\begin{array}{l}\text { Asiakaslähtöisyys } \\
\text { "Asiakkaan prosessi" } \\
\text { Asiakkaan etu }\end{array}$ & $\begin{array}{l}\text { Organisaatiokeskeisyys } \\
\text { "Palvelukokonaisuus" } \\
\text { Organisaation tavoitteet }\end{array}$ & $\begin{array}{l}\text { Toimenpidekeskeisyys } \\
\text { "Valinnanvapaus palvelukonseptista" } \\
\text { Toimenpiteet keinoina }\end{array}$ \\
\hline $\begin{array}{l}\text { Asiakkaan } \\
\text { elämäntilanne } \\
\text { Asiakkuus }\end{array}$ & $\begin{array}{l}\text { - elämäntilanteen selvittely } \\
\text { - palvelutarpeet ja tavoitteet } \\
\text { - asiakkuuskriteerit } \\
\text { - asiakkuusprosessi, osallisuus }\end{array}$ & $\begin{array}{l}\text { - avokonttorissa tapaaminen } \\
\text { - velvoitteet, kontrolli, sanktiot } \\
\text { - palvelun laatu vs. asiakasmäärät } \\
\text { - asiakkuus siirretään eteenpäin }\end{array}$ & $\begin{array}{l}\text { - huomio toimenpiteisiin } \\
\text { - esitellään palvelutarjotin } \\
\text { - palvelukonseptit } \\
\text { - asiakkuuksien nopea läpivirtaus }\end{array}$ \\
\hline $\begin{array}{l}\text { Järjestys } \\
\text { Muutos }\end{array}$ & $\begin{array}{l}\text { - tavoitteet, keinot, suunnitelma } \\
\text { - työelämä-, koulutustavoite } \\
\text { - tavoitteellinen muutostyö } \\
\text { - luottamus, asiakasprosessi }\end{array}$ & $\begin{array}{l}\text { - toimiva palvelukokonaisuus } \\
\text { - yhteispalvelun vastuutyöntekijä } \\
\text { - viranomaisten suunnitelmat } \\
\text { - ellei muutosta, asiakkuus siirretään }\end{array}$ & $\begin{array}{l}\text { - työllisyys, kuntoutus tai koulutus } \\
\text { - toimenpiteiden aikataulutus } \\
\text { - näennäinen valinnanvapaus } \\
\text { - asiakas raportoi muutoksesta }\end{array}$ \\
\hline
\end{tabular}

Kuvio 1. Asiakaslähtöisyys, organisaatiokeskeisyys ja toimenpidekeskeisyys TYP_ yhteispalvelussa

Analyysin tulokset on kiteytetty kuviossa 1 siten, että asiakkaan elämäntilannetta ja asiakkuutta sekä järjestystä ja muutosta TYP-palvelussa on tarkasteltu asiakaslähtöisyyden, organisaatiokeskeisyyden ja toimenpidekeskeisyyden näkökulmista. Näitä kolmea työorientaatiota on kuvattu aineistossa monin tavoin ja paikoitellen päällekkäin. Kiteytyksenä kolmea työorientaatiota voi luonnehtia siten, että asiakaslähtöisessä työotteessa varmistettiin asiakkaan prosessi, organisaatiokeskeisessä käytännössä huolehdittiin palvelukokonaisuudesta ja toimenpidekeskeisessä työotteessa asiakkaalle tarjottiin valinnanvapautta palvelukonseptista. Kaikissa työorientaatioissa toteutui asiakaslähtöisen työskentelyn piirteitä, mutta lakisääteisyys ja velvoittavuus ohjasivat toimintaa vahvasti toimenpidekeskeisyyteen.

\section{YHTEENVETO JA JOHTOPÄÄTÖKSET}

Tutkimuksessa on tarkasteltu asiakaslähtöisyyden esiintymistä lakisääteisen ja monialaisen TYP-yhteispalvelun asiakastyössä työntekijöiden kuvaamana. TYP-toiminnan tavoite on tarjota henkilökohtaista, kasvokkain tapahtuvaa palvelua (HE 183/2014; Kerminen
2015) ja siinä tavoitellaan asiakaslähtöisyyttä. Asiakaslähtöisyydestä on tullut palvelujen kehittämisen avainsana. Asiakkuuteen liitetään muun muassa käsitteet kuulluksi tuleminen, osallisuus, vastavuoroisuus, itsemäärääminen ja subjektina toimiminen (Laitinen 2008).

Tässä artikkelissa on analysoitu, millä tavoin asiakaslähtöisyys esiintyy työntekijöiden puheessa monialaisessa TYP-palvelussa. Tutkimusaineistona ovat TYP-työntekijöiden 19 teemahaastattelua. Haastateltavat kuvasivat asiakaslähtöisyyttä usein lähes itsestäänselvyytenä. Useimmat kuvasivat asiakaslähtöistä työotetta monipuolisesti, osa kuvasi sitä toimenpiteiden käsitteillä ja osa ohitti kysymyksen asiakaslähtöisyydestä. Analyysitaulukko on muodostettu käsitepareista asiakkaan elämäntilanne ja asiakkuus, järjestys ja muutos sekä käsitteistä asiakaslähtöisyys, organisaatiokeskeisyys ja toimenpidekeskeisyys, joita tarkasteltiin kolmena työorientaationa.

TYP-palvelun monialainen yhteistyö toteutti tehtäväänsä aktivoida ja osallistaa työttömiä kohti avoimia työmarkkinoita. Monialainen yhteistyö sai aikaan järjestystä ja muutosta asiak- 
kaan elämäntilanteeseen ja palvelujärjestelmän asiakkuuteen (Strauss 1978). Työskentelyn vaiheita olivat palvelutarvekartoitus, monialaisen työllistymissuunnitelman laatiminen ja palvelun toteutumisen seuranta. TYP-palvelussa selvitettiin asiakkaan elämäntilanne ja palvelutarpeet, laadittiin työllistymissuunnitelma asiakkaan tavoitteiden pohjalta ja asiakkaan tehtävänä oli toteuttaa suunnitelma sekä informoida työntekijöitä tilanteesta.

Asiakastyön voi katsoa toteutuneen TYP-palvelussa monelta osin vastavuoroisesti ja asiakaslähtöisesti. Yhteispalvelun lähtökohtana lakisääteisyys, viranomaistoiminta ja velvoittavuus ohjasivat asiakastyötä organisaatio- ja toimenpidekeskeisyyteen. Useimmat työntekijät katsoivat, että he pystyvät toimimaan hyvinkin asiakaslähtöisesti, ja että se on heidän työtään ohjaava keskeinen periaate. Asiakaslähtöisyyttä kuvattiin asiakkaan kuuntelemisena, vastavuoroisena kohtaamisena sekä henkilön tavoitteiden ja toiminnan tukemisena. Tavoitteena oli ymmärtää, mihin henkilö kaipaa apua, jotta pystyisi työllistymään tai opiskelemaan. Ensisijaisesti asiakasta pyrittiin auttamaan, että hän voisi toteuttaa omaa suunnitelmaansa.

Tutkimuksen tuloksena jäsentyi asiakaslähtöinen, organisaatiokeskeinen ja toimenpidekeskeinen työorientaatio TYP-palvelussa. Näitä asiakastyön käytäntöjä kuvattiin aineistossa monin eri tavoin ja paikoitellen päällekkäin, myös siten, että asiakaslähtöisyyttä kuvattiin ja määriteltiin organisaation lähtökohdista tai toimenpiteiden käsitteillä.
Asiakaslähtöisessä työskentelyssä lähdettiin liikkeelle asiakkaan elämäntilanteesta ja tavoitteista. Keskustellen ja kuunnellen pyrittiin rakentamaan luottamuksellinen yhteistyö ja pohjaa tavoitteelliselle muutostyölle. Asiakkaan kanssa toimittiin vastavuoroisesti ja varmistettiin hänen osallisuutensa asiakkuusprosessissa. Yhteistyössä selvitettiin työllistymisen esteitä ja etsittiin voimavaroja ja ratkaisuvaihtoehtoja. Asiakaslähtöisen työotteen voi tiivistää asiakkaan prosessin tukemiseksi, jossa keskeistä on asiakkaan etu ja asiakkaan omien tavoitteiden tukeminen.

Organisaatiokeskeisessä työskentelyssä korostuivat toiminnan lakisääteiset velvoitteet, tuki ja kontrolli. Luottamuksen syntymistä heikensi viranomaisten mahdollisuus sanktioihin ja asiakkaan henkilökohtaisten asioiden käsittely avokonttorissa. Viranomaiset laativat asiakkaalle työllistymissuunnitelman ja palvelukokonaisuuden organisaatioiden lähtökohdista. Ellei asetettuja tavoitteita saavutettu, asiakas voitiin siirtää eteenpäin toisiin palveluihin. Asiakastyössä pyrittiin vastaamaan organisaation asettamiin määrällisiin tavoitteisiin. Organisaatiokeskeisyyttä voi kuvata palvelukokonaisuutena, jota toteutetaan organisaation lähtökohdista ja tavoitteista käsin.

Toimenpidekeskeisessä työskentelyssä asiakkaan tilannetta ratkottiin monialaisesti palvelukonseptien avulla. Asiakkaalle esiteltiin muun muassa palvelutarjotinta, josta hän valitsi itselleen sopivat palvelut ja hänet ohjattiin erilaisiin työllistymisen tukitoimiin ja toimenpiteisiin. Palveluissa toteutui valinnanvapaus ja silloin, kun tilanne ei asettunut organisaation palvelukonseptiin, asiakas voitiin siirtää eteenpäin toisiin palveluihin. Palveluprosessi voi- 
tiin pilkkoa toimenpiteisiin ja muodostaa kuva toiminnan tehokkuudesta ja tuloksellisuudesta (Arnkil ym. 2015; Tonttila 2015). Toimenpidekeskeisyyden voi tiivistää valinnanvapaudeksi rajatussa palvelukonseptissa, jossa toimenpiteet nähdään keinoina tukea asiakasta.

Kaikissa asiakastyön orientaatioissa, myös organisaatio- ja toimenpidekeskeisessä työskentelyssä, työntekijät kuvasivat asiakaslähtöisen työskentelyn piirteitä. Vaikka asiakas valitsisi palvelukonseptista toimenpiteen, se ei välttämättä ole asiakaslähtöinen, jolloin asiakas voi ohjautua työntekijöiden toimenpiteiden kohteeksi. Usein työntekijät kuvasivat asiakaslähtöisyyttä toimenpiteiden käsitteillä. Asiakaslähtöinen ja toimenpiteisiin keskittyvä työote jakoivat myös työntekijöiden näkemyksiä työn tuloksellisuuden paineissa. Tämä muodosti asiakastyön ja byrokratiatyön välisen jännitteen (myös Heinonen 2009, 26-27). Aulikki Kananoja (1996) on esittänyt jo parikymmentä vuotta sitten vaatimuksen, että "hallintokeskeisestä ja toimenpiteitä jakavasta toimintamallista on päästävä eroon". Toimenpidekeskeinen työote soveltuu kuitenkin erityisen hyvin laaja-alaisiin palvelukonsepteihin.

Työttömille työnhakijoille TYP-asiakkuus on lakisääteisenä velvoittava, ja työntekijän tarkoittama tuki voi muuttua kontrolliksi. Asiakkaita kannustettiin asioiden hoitoon ja oman elämänsä ohjaajaksi. Joskus käytettiin pakkoa ja joskus asiakas saattoi vetäytyä kokonaan palveluista. Silloin, kun tilanne ei asettunut organisaation palvelukonseptiin, asiakkuutta voitiin ratkaista ohjaamalla henkilö toistuvasti uusiin palveluihin. Joidenkin haastateltavien mukaan tämä saattoi osaltaan kasvattaa mahdollisuutta sosiaaliseen syrjäytymiseen.

Haastatteluaineisto on hyvin rajallinen ja koskee Uudenmaan kuuden TYPverkoston työntekijöitä. Haastateltavat olivat kunnan, TE-toimiston ja Kelan työntekijöitä kaikista yhteistyöorganisaatioista. Aineistoa on analysoitu sekä aineistolähtöisesti että teoriaohjaavasti. Työntekijöiden kuvauksia on analysoitu asiakkaan tilanteen ja asiakkuuden sekä järjestyksen ja muutoksen tasoilla. Toiseksi aineistoa on analysoitu aineistolähtöisesti kolmen työorientaation ulottuvuuksilla. Analyysin tulokset ja tehtyjen tulkintojen perusteet on pyritty tutkimuksessa osoittamaan aineistositaatein ja keskeiset tulokset on koottu analyysitaulukkoon (Kuvio 1).

Tutkimuskirjallisuudessa eri viranomaistahoja kuvaavat työorientaatiot vastaavat pitkälti tämän tutkimuksen tuloksia. Sosiaalipalveluissa viranomaiset nähdään usein asiantuntevina tietäjinä ja asiakaslähtöisinä ymmärtäjinä (Jokinen 1995, 145). TE-palveluja toteutetaan keskeisesti palveluohjauksena ja toisaalta toimenpidekeskeisinä suoritteina (Arnkil ym. 2015, 68-72). Kelassa tehtävä asiakaspalvelutyö on pääasiassa neuvontatyötä, jossa hoidetaan asioita, ei asiakkaita, mutta palveluissa toimitaan asiakaslähtöisesti (Heinonen 2009, 35-36). Hallintokulttuuria ohjaa näkemys, jonka mukaan ensin tulee palvelujärjestelmä ja sitten vasta asiakas (Dogan 2006, 66). Tutkimuksessa asiakastyön erilaiset lähestymistavat ja työorientaatiot kuvasivat myös TYPpalvelun taustaorganisaatioiden, ammatillisten työtapojen ja yhteistyökäytäntöjen piirteitä ja yhteensovittamisen haasteita. 


\section{KirjallisuUs}

Alasuutari, Pertti (1999) Laadullinen tutkimus. Tampere:Vastapaino.

Arnkil, Robert \& Spangar, Timo \& Jokinen, Esa \& Tuusa, Matti \& Pitkänen, Sari (2015) Kokonaisvoimavarat käyttöön työllisyyden edistämisessä. Työllisyyden kuntakokeilun (2012-2015) seurantatutkimuksen loppuraportti. Työ- ja elinkeinoministeriön julkaisuja, Työ ja yrittäjyys 47/2015. Helsinki: Työ- ja elinkeinoministeriö.

Ashorn, Ulla \& Autti-Rämö, Ilona \& Lehto, Juhani \& Rajavaara, Marketta (2013) (toim.) Kuntoutus muuttuu - entä kuntoutusjärjestelmä? Kelan tutkimusosasto. Helsinki: Kela.

Clasen, Jochen \& Clegg, Daniel (2006) Beyond Activation: Reforming European Unemployment Protection Systems in Post-industrial Labour Markets. European Societies 8 (4), 527-553. https:// doi.org/10.1080/14616690601002582

Davies, Bleddyn \& Challis, David (1986) Matching Resources to Needs in Community Care. Aldershot: Ashgate.

Dogan, Minna (2006) Sosiaaliasiamiehet asiakkaan aseman ja oikeuksien edistäjinä. Helsinki: Sosiaali- ja terveysturvan keskusliitto.

Elonen, Noora \& Niemelä, Jukka \& Saloniemi, Antti (2017) Aktivointi ja pitkäaikaistyöttömien monenlainen toimijuus. Janus 25 (4), 280-296.

Epstein, Ronald \& Fiscella, Kevin \& Lesser, Cara \& Stange Kurt (2010) Why The Nation Needs A Policy Push On Patient-Centered Health Care. Health Affairs 29 (8) 1489-1495. https://doi. org $/ 10.1377 /$ hlthaff.2009.0888

Fook, Jan (2002) Social Work. Critical theory and practice. London: Sage.

Freidson, Elliot (2001) Professionalism. The Third Logic. Chicago: University of Chicago Press.

Freire, Paulo (2005) Sorrettujen pedagogiikka. Tampere:Vastapaino.

HE 183/2014 vp. Hallituksen esitys eduskunnalle laiksi työllistymistä edistävästä monialaisesta yhteispalvelusta sekä eräiksi siihen liittyviksi laeiksi.

Heinonen, Hanna-Mari (2009) Byrokraat- ti vai asiakaspalvelija? Kelan virkailijan toimintatavat ja roolit Yhteyskeskuksessa palvelukulttuurin muutosten keskellä. Kela: Sosiaali- ja terveysturvan tutkimuksia 106.

Heinonen, Tuula \& Spearman, Len (2010) Social Work Practice. Problem solving and beyond. 3. painos. Toronto: Nelson Education.

Hvinden, Bjørn (1999) Activation: a Nordic Perspective. Teoksessa Linking Welfare and Work. European Foundation for the Improvement of Living and Working Conditions. Luxembourg: Office for Official Publications of the European Communities, 27-42.

Hänninen, Kaija (2000) Asiakaslähtöistä täsmäpalvelua vauvasta vaariin. Raportteja 20/2007. Helsinki: Stakes.

Jokinen, Arja (1995) Neuvottelu asiakkaan identiteetistä. Teoksessa Arja Jokinen, Kirsi Juhila \& Tarja Pösö (toim.) Sosiaalityö, asiakkuus ja sosiaaliset ongelmat. Helsinki: Sosiaaliturvan keskusliitto, 127-154.

Kananoja, Aulikki (1996) Hyvinvointipalvelut lähelle asiakkaiden arkea. Kuntalehti 3/1996, 16-17.

Kananoja, Aulikki (1997) Julkisten palvelujen ydintehtävät asiakaspalautteen viitekehyksenä. Teoksessa Tuula Salmela (toim.) Autetaanko asiakasta, palvellaanko potilasta. Jyväskylä: Atena Kustannus, 109-123.

Kerminen, Päivi (2015) Työllistymistä edistävä monialainen yhteispalvelu (TYP). Vatespäivät 5.-6.5.2015. https://www.vates.fi/media/projektit/ tiivistelmat_2015/5.-6-5.2015-typ-kerminen.pdf Luettu 1.8.2017.

Kiikkala, Irma (2000) Asiakaslähtöisyys toiminnan periaatteena sosiaali- ja terveydenhuollossa. Teoksessa Susanna Nouko-Juvonen, Pekka Ruotsalainen \& Irma Kiikkala (toim.) Hyvinvointivaltion palveluketjut. Helsinki: Tammi, 112-121.

Kilpeläinen, Arja (2009) Luhmannin ekologinen kommunikaatio teoreettisena lähestymistapana sosiaalityössä. Teoksessa Mikko Mäntysaari, Anneli Pohjola \& Tarja Pösö (toim.) Sosiaalityö ja teoria. Jyväskylä: PS-kustannus, 67-84.

Kokko, Riitta-Liisa (2003) Asiakas kuntoutuksen yhteistyöryhmässä. Institutionaa- 
lisen kohtaamisen jännitteitä. Kuntoutussäätiön tutkimuksia 72/2003. Helsinki: Yliopistopaino.

Kokko, Riitta-Liisa \& Veistilä, Minna (2016) Sosiaalityö ja sosiaalinen kuntoutus yhteistyönä. Teoksessa Maritta Törrönen, Kaija Hänninen, Päivi Jouttimäki, Tiina Lehto-Lundén, Petra Salovaara \& Minna Veistilä (toim.) Vastavuoroinen sosiaalityö. Helsinki: Gaudeamus, 220-230.

Laitinen, Maarit (2008) Valta ja asiakaslähtöisyys viranomaiskohtaamisissa. Lahtelaisten asiakkaiden kertomuksia työttömyyden ajalta. Tampere: Tampereen yliopisto.

Laki työllistymistä edistävästä monialaisesta yhteispalvelusta 1369/2014.

Needham, Catherine (2013) Personalising public services. Understanding the personalisation narrative. Bristol: Policy Press.

Nummela, Tuija (2011) Asiakkaan asema ja oikeuksien toteutuminen aikuissosiaalityössä. Dissertations in Social Sciences and Business Studies No 17. Kuopio: ItäSuomen yliopisto.

Parton, Nigel \& O’Byrne, Patrick (2000) Constructive Social Work. Towards a new practice. Basingstoke: Macmillan.

Payne, Malcom (1997) Modern social work theory. $2^{\text {nd }}$ edition. Basingstoke: Macmillan. https://doi.org/10.1007/978-1349-14284-2

Rajavaara, Marketta (2014) Yksilöllisestä henkilökohtaiseksi? Henkilökohtaistaminen hyvinvointipolitiikan uudistusideana. Teoksessa Riitta Haverinen, Marja Kuronen \& Tarja Pösö (toim.) Sosiaalihuollon tila ja tulevaisuus. Tampere: Vastapaino, 141-160.
Ratkaisujen Suomi (2015) Pääministeri Juha Sipilän hallituksen strateginen ohjelma 29.5.2015. Hallituksen julkaisusarja 10/2015.

Rissanen, Päivi (2015) Toivoton tapaus? Autoetnografia sairastumisesta ja kuntoutumisesta. Kuntoutussäätiön tutkimuksia 88/2015. Helsinki: Unigrafia.

Rose, Stephen M \& Black, Bruce L (1985) Advocacy and Empowerment. Mental Health care in the community. Boston: Routledge \& Paul Kegan.

Ruotsalainen, Pekka (2000) Asiakaslähtöinen palveluketju ja tietoteknologia. Teoksessa Susanna Nouko-Juvonen, Pekka Ruotsalainen \& Irma Kiikkala (toim.) Hyvinvointivaltion palveluketjut. Helsinki: Tammi, 7-32.

Sipilä, Anita (2011) Sosiaalityön asiantuntijuuden ulottuvuudet - Tiedot, taidot ja etiikka työntekijöiden näkökulmasta kunnallisessa sosiaalityössä. Dissertations in Social Sciences and Business Studies No 28. Kuopio: Itä-Suomen yliopisto.

Sosiaalihuoltolaki 1301/2014.

Strauss, Anselm (1978) Negotiations. Varieties, Contexts, Processes and Social Order. San Francisco:Jossey-Bass Publishers.

Tonttila, Jarkko (2015) Työpolitiikan palvelurakennearviointi: "Asiakaslähtöisempää ja tuloksellisempaa palvelua". Työ- ja elinkeinoministeriön julkaisuja 1/2015. Helsinki:Työ- ja elinkeinoministeriö.

Tuomi, Jouni \& Sarajärvi, Anneli (2013) Laadullinen tutkimus ja sisällönanalyysi. Jyväskylä: Gummerus.

Yin, Robert K. (2014) Case study research. Design and methods. 2nd edition. Thousand Oaks: Sage Publications. 